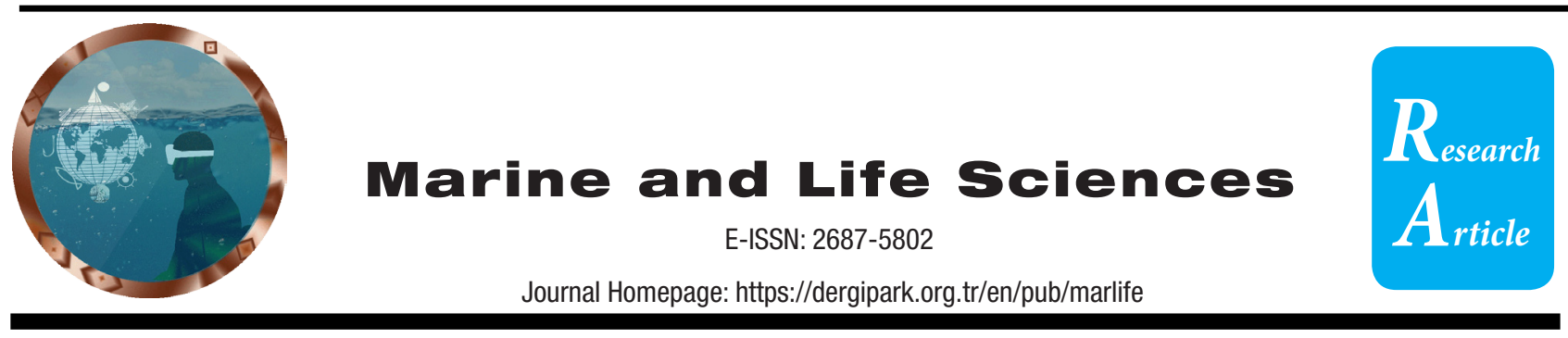

\title{
A mixed Bacillus gibsonii and Sphingomonas echinoides infection in cultured rainbow trout (Oncorhynchus mykiss)
}

\author{
Özgür Çanak ${ }^{1 *}$, Tülay Akaylı' ${ }^{1}$, Çiğdem Ürkü ${ }^{1}$
}

*Corresponding author: ocanak@istanbul.edu.tr

Received: 23.09 .2021

Accepted: 30.10 .2021

Affiliations

IIstanbul University, Faculty of Aquatic

Sciences, Department of Fish Diseases,

Ordu Cad. No:8 Laleli İstanbul, TURKEY

\section{ABSTRACT}

Rainbow trout (Oncorhynchus mykiss) is a fish species with a long history of cultivation and bacterial pathogens are limiting the success rate. The aim of this study is the biochemical and molecular identification of two opportunistic pathogens detected in the rainbow trout cultured in net cages in a dam lake located on the Kızılırmak river; revealing the pathological symptoms of them in the moribund fish samples; determination of their antimicrobial susceptibility profile and determination of the antagonistic effect of two probiotic-candidate strains against them. Depending on the results of the conventional bacteriologic and molecular identification studies, bacterial isolates recovered from the internal organs of the moribund fish samples, a mixed bacterial infection case of Bacillus gibsonii and Sphingomonas echinoides was identified in the moribund fish samples showing general bacterial hemorrhagic septicemia symptoms for the first time in rainbow trout. Despite it was not possible to identify these isolates at the species level using conventional bacteriological methods, our isolates separately showed similarities more than $99 \%$ with the above mentioned species in the 16s RNA sequence analysis. The results of this study showed that, long term water quality parameter determination and bacterial distribution monitoring studies which include molecular tools should be carried out in the aquaculture sites to increase the success in trout culture.

\section{Keywords}

Aquaculture

Fish diseases

Rainbow trout

Bacillus gibsonii

Sphingomonas echinoides new emerging or opportunistic pathogens were detected. Various bacterial pathogens, both Gram-negative (representatives of the genera Aeromonas, Vibrio, Pseudomonas etc.) and Gram-positive (representatives of the genera Staphylococcus, Streptococcus and Lactococcus etc.) were identified in rainbow trout cultured in Turkey in a great number of previous studies (Muz et al., 1995; Kan and Sarıeyyüpoğlu, 2008; Türe et al., 2012; Öztürk et al., 2013; Balta and Balta, 2019; Akaylı et al., 2020; Akaylı et al., 2021). Besides widely distributed and repeatedly isolated pathogens, some bacterial inhabitants of the aquatic environment may cause infections as opportunistic pathogens in stressed fish under rapidly changing environmental conditions (Austin and Austin, 2016). 
The aim of this study is the biochemical and molecular identification of two opportunistic pathogens detected in the rainbow trout cultured in net cages in a dam lake located on the Kızilırmak river; revealing the pathological symptoms of them in the moribund fish samples; determination of their antimicrobial susceptibility profile and determination of the antagonistic effect of two probiotic-candidate strains against them.

\section{Material and Methods}

\section{Field sampling}

A rainbow trout cage farm in a dam lake located on Kızılırmak river, in Bafra-Samsun region was visited five times (April, May, June, September and late October 2017) for field sampling. A total of 10 rainbow trout samples (100-300 g) with various clinical symptoms were analyzed in each sampling visit. Bacteriological samples were taken from liver, spleen and kidney of moribund fish samples and streaked onto TSA (Trypticase Soy Agar, Merck) and incubated at $22^{\circ} \mathrm{C}$ for $72 \mathrm{~h}$ for bacterial growth (Roberts, 2012; Austin and Austin, 2016). In this article, the results of the late October sampling will be discussed.

\section{Bacterial identification}

Bacterial colonies that were isolated from the internal organs of moribund fish samples collected in late October were purified and identified with conventional discriminative laboratory tests (Yabuuchi and Kosako, 2005; Logan and De Vos, 2009; Roberts, 2012; Austin and Austin, 2016). Later, bacterial DNA samples were isolated from the pure bacterial cultures with High Pure PCR Template Preparation Kit (Roche, Switzerland). Universal primers 27F (5'-AGA GTT TGA TCM TGG CTC AG-3') and 907R (5'-CCG TCA ATT CMT TTR AGT TT-3') targeting a part of $16 \mathrm{~S}$ / 23 S gene (Lane, 1991) and PCR Master Mix 2X (Fermantas, K 0171) were used for the PCR amplification. PCR amplification steps were used as described by Lane (1991). An 880 bp region of 16s RNA sequence analysis was performed with ClustalX 2.1 (Larkin et al., 2007) and BLASTN 2.2.20 (Zhang et al., 2000) algorithms on Bioedit v7.0.0 software (Hall, 1999).

\section{Histopathology}

Tissue samples (spleen, kidney, liver etc.) were fixed in \%10 buffered formalin and processed for paraffin embedding. Histological sections $(4-5 \mu \mathrm{m})$ were stained with hematoxylin and eosin $(\mathrm{H} \& \mathrm{E})$ and analyzed under light microscope (Roberts, 2012).

\section{Antibiogram susceptibility profile}

Modified Kirby-Bauer disc diffusion method (Bhunia et al., 1988) was used for the determination of antibiotic resistance profile of bacterial isolates against sulphametaxozole-trimethoprim, amoxicillin, tetracycline, florfenicole, erythromycin, enrofloxacine, oxolinic acid and ciprofloxacine with three replicates. Three replicates of Mueller-Hinton medium containing petri dishes were incubated at $22^{\circ} \mathrm{C}$ for $48 \mathrm{~h}$ and inhibition zone diameters were measured and evaluated according to the CLSI standards (Wikler, 2006). Inhibition zones with a diameter of $0-1.5 \mathrm{~cm}$ were regarded as resistant; 1.6-2.0 cm were regarded as semi-resistant; 2.1 $\mathrm{cm}$ and above were regarded as sensitive.

\section{Antagonistic effect studies}

Lyophilized Bacillus subtilis (ATCC $6633^{\mathrm{TM}}$ ) and Lactobacillus rhamnosus (ATCC $7469^{\mathrm{TM}}$ ) strains were used as probiotic candidates. Fresh cultures of these strains were used with the modified KirbyBauer disc diffusion method for the determination of antagonism against recovered pathogenic bacteria (Bhunia et al., 1988). Briefly, $200 \mu \mathrm{l}$ of fresh cultures of pathogenic bacteria growth in Nutrient Broth were streaked onto TSA medium to cover all the surface. Later, blank antibiotic susceptibility paper-discs were dipped into fresh cultures of probiotic-candidates growth in Nutrient Broth and placed onto TSA medium. Three replicates of TSA medium containing petri dishes were incubated at $22^{\circ} \mathrm{C}$ for $48 \mathrm{~h}$ and inhibition zone diameters were measured and evaluated according to the CLSI standards (Wikler, 2006). Inhibition zones with a diameter of $0-1.5 \mathrm{~cm}$ were regarded as resistant; 1.6-2.0 cm were regarded as semi-resistant; 2.1 $\mathrm{cm}$ and above were regarded as sensitive.

\section{Results and Discussion}

Many freshwater rivers flows through the northern part of Turkey (also called as the Black Sea Region), there are many dam lakes on these rivers, and most of them host aquaculture facilities. Previously motile Aeromonads (Muz et al., 1995), Streptococcus faecalis (Kan and Sarıeyyüpoğlu, 2008) and Lactococcus garvieae (Türe et al., 2012; Öztürk et al., 2013; Balta and Balta, 2019) were recovered and identified as bacterial pathogens of rainbow trout cultured in various dam lakes in Turkey. During this one year monitoring study, various other infection cases were also detected; A mixed infection case that was caused by Frigoribacterium faeni and Lactococcus garvieae was detected in April (Akaylı et al., 2020), a Citrobacter freundii infection case was detected 
in June and a Hafnia alvei infection case was detected in September samples (Akaylı et al., 2021).

In moribund fish samples analyzed in the October sampling where the water temperature was $18^{\circ} \mathrm{C}$, darkening of the skin and loss of scales was observed. As observed in many of the previous bacterial haemmorhagic septicemia cases of rainbow trout caused by various pathogens (Roberts, 2012; Austin and Austin, 2016) hemorrhages and exophthalmos in the eyes was a common phenomenon in these samples where in some of them loss of eyes was observed (Figure 1a). In many samples, internal organs (kidney and spleen) preserved their healthy appearance, but their pale livers were mostly covered with petechial hemorrhages (Figure 1b).
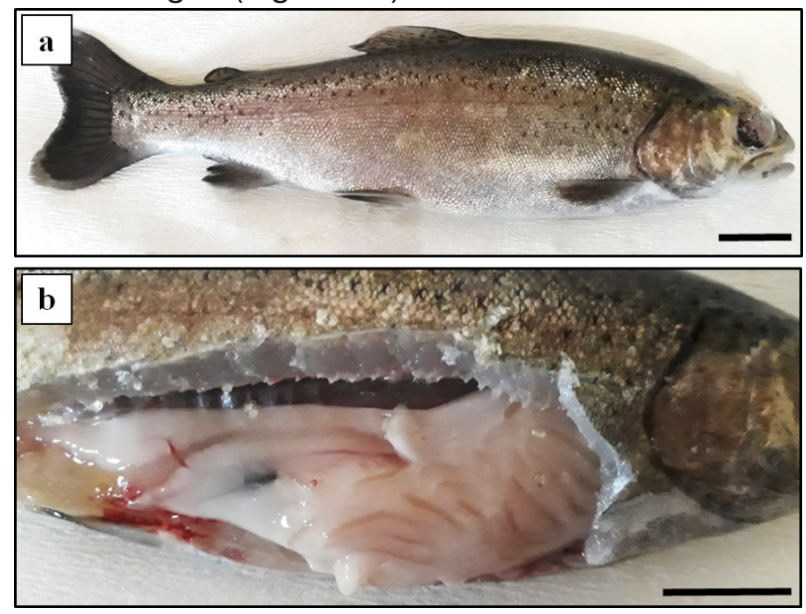

Figure 1. (a) Darkening of the skin, loss of scales and loss of eyes in moribund rainbow trout sample (b) Apparently healthy kidney and accumulation of fat tissue in the internal examination of a moribund rainbow trout sample. Scale bars: $2 \mathrm{~cm}$

Depending on the results of the conventional bacteriologic and molecular identification studies, bacterial isolates recovered from the internal organs of the moribund fish samples, a mixed bacterial infection case of Bacillus gibsonii (Figure 2a) and Sphingomonas echinoides (Figure 2b) was identified in the October samples. Despite it was not possible to identify these isolates at the species level using conventional bacteriological methods (Table1), our isolates separately showed similarities more than 99\% with the above mentioned species in the 16s RNA sequence analysis. Despite they are found to be sensitive or semi-sensitive against most of the antibiotic compounds that are commonly used in aquaculture, the probiotic candidates used in this study did not show a strong antagonistic effect against these opportunistic pathogens (Table
1). B. subtilis showed weak antagonistic effect against $B$. gibsonii and $S$. echinoides isolates and L. rhamnosus showed negative antagonistic effect against $B$. gibsonii and $S$. echinoides isolates (Figure 3).
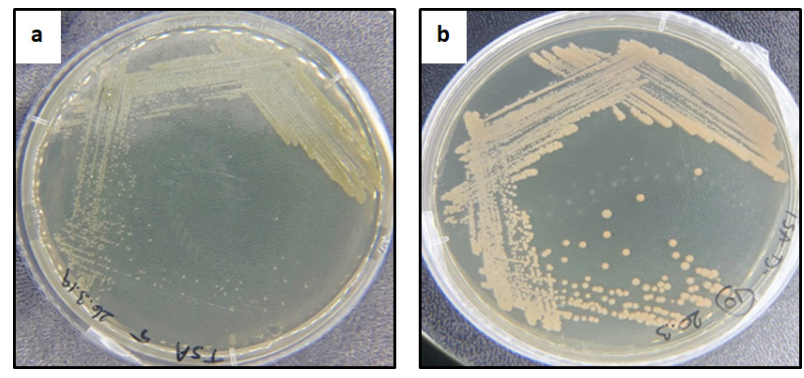

Figure 2. (a) Yellowish and round colonies of Bacillus gibsonii with a 2-3 $\mathrm{mm}$ diameter on TSA medium (b) Yellowish-creamy and round colonies of Sphingomonas echinoides with a 4-6 mm diameter on TSA medium
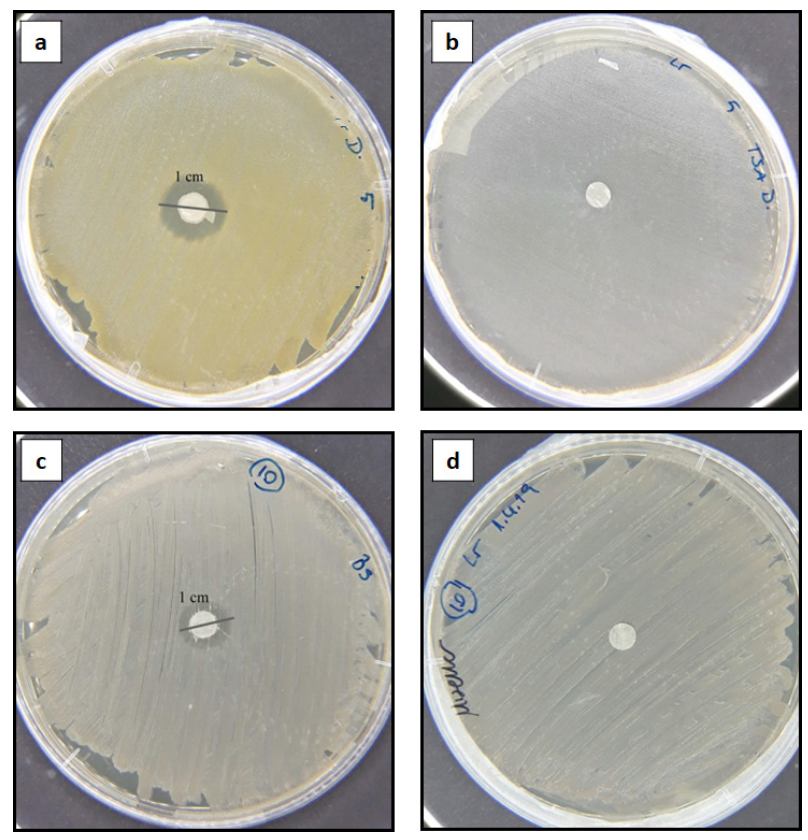

Figure 3. (a) Weak antagonistic effect of Bacillus subtilis against Bacillus gibsonii (b) Negative antagonistic effect of Lactobacillus rhamnosus against Bacillus gibsonii (c) Weak antagonistic effect of Bacillus subtilis against Sphingomonas echinoides (d) Negative antagonistic effect of Lactobacillus rhamnosus against Sphingomonas echinoides

In this study, histopathological effects of these opportunistic pathogens on the internal organs of moribund fish samples were revealed. Despite many organs such as kidney and spleen, looked apparently healthy during the clinical examination, histopathologic observations proved that this mixed infection caused a classical bacterial hemorrhagic septicemia. Histopathologically, samples co-infected with $B$. gibsonii and $S$. echinoides showed mass hyperemia in the liver 
Table 1. Phenotypic and biochemical characteristics, antimicrobial profile and antagonistic effect profile of the bacterial isolates

\begin{tabular}{|c|c|c|c|c|c|}
\hline $\begin{array}{l}\text { Biochemical } \\
\text { characteristics }\end{array}$ & B. gibsonii $\mathrm{n}=4$ & S. echinoides $\mathrm{n}=7$ & $\begin{array}{c}\text { Antibiotic and } \\
\text { antagonistic effect }\end{array}$ & B. gibsonii $\mathrm{n}=4$ & S. echinoides $\mathrm{n}=7$ \\
\hline Colony colour & yellowish & light yellow & S.metax / Trimet & $\mathrm{R}$ & $\mathrm{R}$ \\
\hline Gram & + & - & Ciprofloxacine & S & $\mathrm{SR}$ \\
\hline Motility & + & + & Amoxicillin & $S$ & $\mathrm{SR}$ \\
\hline Oxidase & - & + & Tetracycline & S & S \\
\hline Catalase & + & + & Florfenicole & S & S \\
\hline $\mathrm{O} / \mathrm{F}$ & $\mathrm{F}$ & $\mathrm{O}$ & Erythromycin & $\mathrm{R}$ & SR \\
\hline Indole & - & - & Enrofloxacine & S & SR \\
\hline Methyl Red & - & + & Oxolinic Acid & S & S \\
\hline Vogues-Proskauer & - & - & & & \\
\hline Citrate & - & + & L. rhamnosus & SR & $\mathrm{R}$ \\
\hline Arginine & - & - & B. subtilis & SR & $\mathrm{R}$ \\
\hline Lysine & - & - & \multirow{7}{*}{\multicolumn{3}{|c|}{$\begin{array}{c}\text { +: positive reaction } \quad-\text { : negative reaction F: fermentative } \\
\text { S: sensitive }(>21) \text { SR: semi-resistant }(14-20) \text { R: resistant } \\
(0-13) ; \quad \text { (zone diameters in } \mathrm{mm})\end{array}$}} \\
\hline Ornithin & - & - & & & \\
\hline Lactose & + & - & & & \\
\hline Rhamnose & + & + & & & \\
\hline Maltose & + & - & & & \\
\hline Sorbitol & - & - & & & \\
\hline İnositole & - & - & & & \\
\hline 16s RNA similarity & $99 \%$ & $99 \%$ & & & \\
\hline
\end{tabular}

(Figure 4a), small melanomachrophage centers and slight liquefactive necrosis areas in the kidney (Figure 4b), depletion of the pulps and small hemosiderin accumulation areas in the spleen (Figure 4c), mass hemorrhages around the necrotic hearth muscles (Figure 4d) similar to the general bacterial hemorrhagic septicemia symptoms (Roberts, 2012; Austin and Austin, 2016).
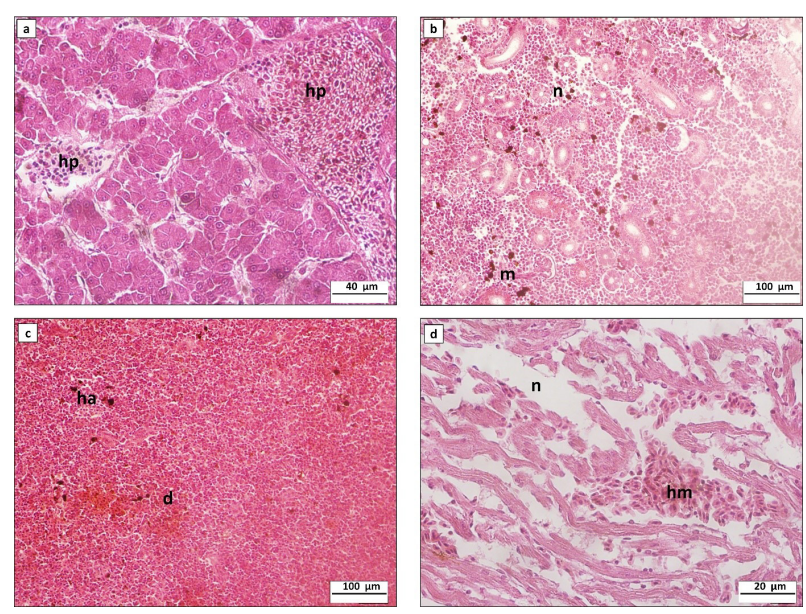

Figure 4. (a) Mass hyperemia [hp] in the liver (b) necrotic areas [n] and melanomacrophage centers [m] in the kidney (c) hemosiderin accumulation [ha] and depletion of the pulps [d] in the spleen (d) and necrotic areas [n] and hemorrhages [hm] in the heart tissues of rainbow trout samples coinfected with B. gibsonii and S. echinoides

When compared with a mix infection case of
Lactococcus garvieae and Frigoribacterium faeni detected in the same sampling area (Akaylı et al., 2020), melanomacrophage centers were found to be smaller but distributed more frequently in the kidney. Also, despite mass hyperemia in a similar rate, the kidney and the spleen tissue cells looked healthier than the infection cases caused by Citrobacter freundii and Hafnia alvei in the same sampling area (Akaylı et al., 2021).

As the human and agricultural activities increase, the water chemistry of the rivers and lakes alternates (Taș, 2006; Tambekar and Dhundale, 2012) and the amount and deposit of organic compounds and chance of the occurrence of bacterial species which degrade these compounds also increases (Bakan et al., 2010; Engin et al., 2017). This may lead an increase in the diversity of the bacterial profile of water and fish and new disease agents are detected (Austin and Austin, 2016). Current research studies were generally focused on the molecular identification of clinical and environmental bacterial species that are sometimes hard to identify with the conventional laboratory methods that rely on the biochemical profile (Yabuuchi and Kosako, 2005; Logan and De Vos, 2009).

Representatives of Bacillus and Sphingomonas genera are distributed in various environments such as soil and water. Some of them are mostly 
environmental species with some benefits by means of biotechnological use, but some species can be pathogenic to other organisms (Yabuuchi and Kosako, 2005; Logan and De Vos, 2009). KızIlırmak River receives substantial loads of nutrients, heavy metals (such as lead), trace metals and other organic compounds, resulting from anthropogenic and agriculture activities within its catchment (Bakan et al., 2010; Engin et al., 2017) which provide these bacteria a good source of carbon (Yabuuchi and Kosako, 2005; Logan and De Vos, 2009). The salinity and alkalinity of the water increases according to the agricultural activities and the dissolving of mineral salts present in the river bed (Taș, 2006).

Representatives of the genus Bacillus, including B. gibsonii is a major source for alkaline pectinase, an enzyme that catalyze the degradation of pectin polymers present in the plant cell walls ( $\mathrm{Li}$ et al., 2005; Deng et al., 2014). Today, pectinases are the upcoming industrially important enzyme having major industrial importance and they hold a leading position among the commercially produced industrial enzymes (Deng et al., 2014; Kavuthodi and Sebastian, 2018). Tambekar and Dhundale (2012) identified B. gibsonii in Lonar Lake (India) with a saline and alkaline character similar to the sampling area of this study. Zhang et al. (2013) characterized a high lead (II) biosorption capacity of $B$. gibsonii and it may find potential low-coast application in industrial wastewater treatment.

B. gibsonii was detected in soil among the bacteria which play major roles in the mineralization of plant-derived materials, of humus, of pesticides, and of hydrocarbons in soil of the agriculture fields (Garbeva et al., 2003). Rafat et al., (2012) identified $B$. gibsonii as an endophytic bacterium in the aerial parts of gotu kola plant (Centella asiatica). B. gibsonii showed antagonistic effect against the fungal pathogen Botrytis cinera in tomato culture (Berrada et al., 2012) and the fungal pathogen Fusarium moniliforme in maize culture (Batool et al., 2019). Sezen et al. (2013) identified $B$. gibsonii from the European mole cricket, Gryllotalpa gryllotalpa collected from Tokat and Trabzon in Turkey and Eski et al. (2017) showed biopesticide effect of this bacterium against coleopterans, particularly against Agelastica alni (Coleoptera: Chrysomelidae) which is one of the serious pests of alder leaf (Alnus sp.) and hazelnut (Corylus sp.). Both of these trees, which can be regarded as a potential source of this bacterium, are commonly distributed along the northern parts of Turkey which includes the sampling area of this study (Dönmez, 2014). Besides, the benefits of various Bacillus species such as probiotic use of B. marisflavi (Akaylı et al., 2015), Orozova et al. (2018) recovered Bacillus mycoides and B. pseudomycoides along with Aeromonas hydrophila from cultured common carp (Cyprinus carpio) and cultured rainbow trout (Oncorhynchus mykiss) suffering from gill disease in Bulgaria.

Besides the other species of the genus Bacillus, the antagonistic properties of $B$. gibsonii was also evaluated against various pathogens. Antagonistic effect of $B$. subtilis was first reported against phytopathogenic fungi due to its ability to the production of antifungal lipopeptidases and good colonization aptitudes (Cazorla et al., 2007). Antagonistic effect of $B$. subtilis against clinical human isolates of $E$. coli due to its fibrinolytic activity (Jeong et al., 2015; Irkitova et al 2018) were also reported. Recently Nannan et al. (2021) reported the bacilycin production ability of $B$. subtilis which is an important antimicrobial peptide that gives this species the opportunity to be evaluated as a probiotic. Antagonistic effect of $B$. subtilis was also evaluated against fish pathogens and Das et al. (2014) reported a strong antagonistic effect against fish originated isolates of Pseudomonas aeruginosa, Edwardsiella tarda, Vibrio parahaemolyticus, Flavobacterium columnare and Staphylococcus aureus, but they also reported a negative antagonistic effect against Aeromonas hydrophila. Also a strong antagonistic effect of $B$. subtilis against fish pathogenic Lactococcus garvieae (Akaylı et al., 2020) and negative antagonistic effect against Frigoribacterium faeni (Akaylı et al., 2020), Citrobacter freundii and Hafnia alvei (Akaylı et al., 2021) recovered from the internal organs of moribund rainbow trout samples was reported. Antagonistic and inhibitory effect of Lactobacillus rhamnosus due to its intestinal cell monolayer colonization ability against $E$. coli (Gopal et al., 2001; Tuo et al., 2013), Salmonella typhimurium (Fayol-Messaoudi et al., 2007; Tuo et al., 2013) and Shigella sonnei (Tuo et al., 2013) and against an opportunistic fungal human pathogen, Candida albicans (Verdenelli et al., 2009) was reported. Recently, in addition to its colonization ability, Federova et al. (2018) reported the ability of this species to produce peptidoglycan hydrolases and endopeptidases and disrupting the peptidoglycan bacterial cell wall. Besides the human clinical isolates, Lactocbacillus rhamnosus was used as a probiotic bacterium especially against Gramnegative pathogens of marine fishes (GomezGil et al., 2000; Ashraf, 2000; Katırcıoğlu, 2001) but it was insufficient to inhibit Gram-positive 
pathogens (Ringo and Gatesoupe, 1998; Burr and Gathlin, 2005). Recently, negative antagonistic effect of $L$. rhamnosus against $L$. garvieae, $F$. faeni (Akaylı et al., 2020), C. freundii and $H$. alvei (Akaylı et al., 2021) recovered from the internal organs of moribund rainbow trout samples was reported.

Sphingonomas echinoides, which was previously classified as Pseudomonas echinoides (Denner et al., 1999) was first isolated as a laboratory contaminant (Heumann, 1960) and it is known to be metabolically versatile and can utilize a wide range of natural compounds as well as some types of environmental contaminants (Shin et al.2012). Although some Sphingomonas species (such as $S$. paucimobilis) are human pathogens, there are also some saprophytic species in the genus besides the ones used in the food, pharmaceutical and mining industries due to their extracellular products, enzymes and ability to degrade the organic compounds (Yabuuchi and Kosako, 2005; Balkwill et al., 2006). S. echinoides is the first marine microorganism exhibiting epoxide hydrolase activity, which is related with carbon assimilation and the metabolism of secondary metabolites from seawater (Kim et al., 2006).

In March 2003, S. echinoides dominated the microbial assemblages in both zones of the lagoon concomitantly with a bloom of filamentous cyanobacteria observed in the freshwater and brackish-water zones of a shallow coastal lagoon of the southwestern Atlantic Ocean, located in Uruguay (Piccini et al., 2006). Kimura et al (2011) detected $S$. echinoides in an extremely acidic and iron-enriched environment due to microbially accelerated oxidative dissolution of the sulfide mineral in a low-temperature $\left(\sim 8.5^{\circ} \mathrm{C}\right)$, longabandoned (>90 years) underground pyrite mine in Wales. Pandey et al. (2021) identified S. echinoides from the microbiome of wheat in India. Singh et al (2015) recovered S. echinoides from the veterinary clinical cases of dogs in India. Demirci (2017) recovered S. echinoides from yogurt samples collected in Turkey. Besides the terrestrial plants, animals and their products, S. echinoides is also present in the aquatic environment and found to be associated with various aquatic organisms. It was previously identified in the intestinal microbiota of cultured grass carp (Ctenopharyngodon idellus) in China (Zhou et al., 2013; Yuan et al. 2015), among the surface-associated bacteria isolated from the sea cucumber Stichopus badionotus in Malaysia (Alipiah et al., 2016), in the microbiota of abalone (Haliotis discus hannai) in South Korea (Lee et al., 2016), among the intestinal microbiota of juvenile sea cucumber, Apostichopus japonicus (Ma et al.,
2018) and among the surface-associated bacteria isolated from the sea urchin (Tripneustes gratilla) in South Africa (Brink et al., 2019). Besides, S. paucimobilis was also identified in the water released from a rainbow trout farm in Mersin region of Turkey (Özer et al., 2008) and a resistant strain of this species against various heavy metals and antibiotics was identified from the water column of Kızılırmak river (Özer et al., 2013; İçgen and Yılmaz, 2014).

Both the genera Bacillus and Sphingomonas include a high number of bacterial species which can be sometimes difficult to distinguish at the species level by using conventional laboratory methods. Almost all of the above mentioned citations used various molecular tools for the identification of $B$. gibsonii and $S$. echinoides as used in this study.

\section{Conclusion}

As discussed above, the interactions of these and other species of the genera Bacillus and Sphingomonas with various environments and organisms were shown and this is the first report of a mixed $B$. gibsonii and $S$. echinoides infection in cultured rainbow trout (O. mykiss). Various environmental bacterial species, including $B$. gibsonii and $S$. echinoides which can be brought to the sampling area from various sources such as plants, soil, agricultural activities, insects etc. by the water of Kızlırmak River that has a high input of organic compounds and various other elements (Ayaz et al., 2012) and these elements provide bacterial growth which may become pathogenic when suitable conditions are found. When considered the economic effects of diseases, the rising antimicrobial resistance problem and other fish welfare and environmental treats, the results of this study showed that, long term water quality parameter determination and bacterial distribution monitoring studies which include molecular tools should be carried out in the aquaculture sites to increase the success in trout culture.

\section{Acknowledgements}

This study was supported by Istanbul University Research Projects coordination unit with the project number: FBA-2018-28476. The authors would like to thank other staff of the project, Dr. Eda YARDIMCI and Dilek OKMEN who were not added to the author list of this manuscript with their own request.The authors also would like to thank the staff of the fish farms for their valuable helps during field sampling. 


\section{COMPLIANCE WITH ETHICAL STANDARDS}

\section{Authors' Contributions}

Some parts of the data obtained from this long-term project was previously presented as an MSc thesis at istanbul University Institute of Science Fish Diseases by Dilek ÖKMEN (Baraj gölü kültür gökkușağı alabalıklarındaki (0. mykiss, W.) patojen bakterilere probiyotiklerin antagonistik etkisi). Authors contributed equally to this paper.

\section{Conflict of Interest}

The authors declare that for this article they have no actual, potential or perceived conflict of interests.

\section{Ethical Approval}

This study was conducted with the permission of Istanbul University Animal Experiments Local Ethical Committee (approved on 23.02.2017).

\section{References}

Akaylı, T., Albayrak, G., Ürkü, Ç., Çanak, Ö. \& Yörük, E. (2015). Characterization of Micrococcus luteus and Bacillus marisflavi recovered from Common Dentex (Dentex dentex) larviculture system. Mediterranean Marine Science, 17(1): 163-169.

Akaylı, T., Çanak, Ö., Yardımcı, R. E., Ürkü, C.. \& Ökmen, D. (2020). A mixed Frigoribacterium faeni and Lactococcus garvieae Infection in cultured Rainbow Trout (0. mykiss). KSU Journal of Agriculture and Nature, 23(6):1569-1577. https://doi.org/10.18016/ksutarimdoga.vi.707820

Akaylı, T., Çanak, Ö., Yardımcı, R. E., Ürkü, Ç. \& Ökmen, D. (2021). Enterobacter infections of cultured Rainbow Trout (Oncorhynchus mykiss). Fresenius Environmental Bulletin, 30(11): 11942-11947.

Alipiah, N. M., Ramli, N. H. S., Low, C.F., Shamsudin, M. \& Yusoff, F. M. (2016). Protective effects of Sea Cucumber surface-associated bacteria against Vibrio harveyi in Brown-Marbled Grouper fingerlings. Aquaculture Environment Interactions, 8:147-155.

Ashraf, A. (2000). Probiotics in fish farming-evaluation of a candidate bacterial mixture, Licentiate thesis, University of Umea.

Austin, B. \& Austin, D. A. (2016). Bacterial fish pathogens, diseases of farmed and wild fish 6th edition. Springer, Dordrecht.

Ayaz, S. Ç., Aktaș, Ö., Dağlı, S., Aydöner, C., Atasoy Aytıș, E. \& Akça, L. (2012). Pollution loads and surface water quality in the Kızılırmak Basin, Turkey. Desalination and Water Treatment, 51(7-9):1533-1542. https://doi.org/10.1080/19443994.2012.698814

Bakan, G., Böke Özkoç, H., Tülek, S. \& Cüce, H. (2010). Integrated environmental quality assessment of Kızlırmak River and its coastal environment. Turkish Journal of Fisheries and Aquatic Sciences, 10: 453-462. https://doi.org/10.4194/trifas.2010.0403

Balkwill, D. L., Fredrickson, J. K. \& Romine, M.F. (2006). Sphingomonas and related genera In: Dworkin, M., Falkow, S., Rosenberg, E., Schleifer, K.H., Stackebrandt, E. (Eds). TheProkaryotes. Springer-Verlag, New York.

Balta F. \& Balta Z. D. (2019). The Isolation of Lactococcus garvieae from eyes of diseased Rainbow Trout (Oncorhynchus mykiss) with Exopthalmia. Journal of Anatolian Environmental and Animal Sciences, 4(1):27-33.

Batool, R., Rehman, S.U., Rafique, M., Amna, A. J., Mukhtar, T., Mahmood, S., Sultan, T., Munis, F.H. \& Chaudhary, H.J. (2019). Biocontrol potential of Bacillus gibsonii and Brevibacterium frigoritolerans in suppression of fusarium stalk rot of maize: a sustainable approach. Asian Journal of Agriculture and Biology, 7(3):320-333.

Berrada, I., Benkhemmar, O., Swings, J., Bendaou, N. \& Amar, M. (2012). Selection of Halophilic bacteria for biological control of Tomato gray mould caused by Botrytis cinerea. Phytopathologia Mediterranea, 51(3): 625-630.

Bhunia, A.K., Johnson, M.C. \& Ray, B. (1988). Purification, characterization and antimicrobial spectrum of Bacteriocin produced by Pediococcus acidilactici. Jorunal of Applied Microbiology, 65: 261-268.

Brink, M., Rhode, C., Macey, B. M., Christison, K. W. \& Rodot-Wilding, R. (2019). Metagenomic assessment of body surface bacterial communities of the Sea Urchin, Tripneustes gratilla. Marine Genomics, 47: 100675

Burr, G., Gathlin, D. (2005). Microbial ecology of the gastrointestinal tract of fish and the potential application of prebiotics and probiotics in finfish aquaculture. Journal of the World Aquaculture Society, 36: 425-436.

Cazorla, F. M., Romero, D., Perez-Garcia, A., Lugtenberg, L. J. J., de Vicente, A. \& Bloemberg, G. (2007). Isolation and characterization of antagonistic Bacillus subtilis strains from the avocado rhizoplane displaying biocontrol activity. Journal of Applied Microbiology, 103: 1950-1959.

Das, B. K., Neha Nidhi, R. G., Roy, P., Muduli, A. K., Swain, P., Mishra, S. S. \& Jayasankar, P. J. (2014). Antagonistic activity of cellular components of Bacillus subtilis AN11 against bacterial pathogens. International Journal of Current Microbiology \& Applied Sciences, 3(5): 795-809.

Demirci, A. (2017). Isolation and characterization of various bacteria in some regional yoghurt samples in Ağrı. MSc. Thesis. Ağrı Ibrahim Çeçen University, Institute of Science.

Deng, A., Zhang, G., Shi, N., Wu, J., Lu, F. \& Wen, T. (2014). Secretory expression, functional characterization, and molecular genetic analysis of novel halo-solvent-tolerant protease from Bacillus gibsonii. Journal of Microbiology and Biotechnology, 24(2): 197-208.

Denner, E. B. M., Kämpfer, P., Busse, H. J. \& Moore, E. R. B. (1999). Reclassification of Pseudomonas echinoides Heumann 1962, 343AL, in the genus Sphingomonas as Sphingomonas echinoides comb. nov. International Journal of Systematic Bacteriology, 49: 1103-1109.

Dönmez, Y. (2014). Studies on vegetation geography of Turkey. İstanbul Üniversitesi Edebiyat Fakültesi Coğrafya Bölümü Coğrafya Dergisi, $29:$ 1-27.

Engin, M. S., Uyanık, A. \& Cay, S. (2017). Investigation of trace metals distribution in water, sediments and wetland plants of Kızlırmak Delta, Turkey. International Journal of Sediment Research, 32: 90-97.

Eski, A., Demir, I., Sezen, K. \& Demirbağ, Z. (2017). A new biopesticide from a local Bacillus thuringiensis var. tenebrionis (Xd3) against alder leaf beetle (Coleoptera: Chrysomelidae). World Journal of Microbiology and Biotechnology, 33(5): 95. https://doi.org/10.1007/s11274-017-2263-0

Fayol-Messaoudi, D., Coconnier-Polter, M. H., Lievin-Le Moal, V., Atassi, F., Berger, C. N. \& Servin, A. L. (2007). The Lactobacillus plantarum Strain ACA- 
DC287 isolated from a Greek cheese demonstrates antagonistic activity in vitro and in vivo against Salmonella enterica serovar typhimurium. Journal of Applied Microbiology, 103: 657-665.

Fedorova, T. V., Vasina, D. V., Begunova, A. V., Rozhkova, I. V., Raskoshnaya, T. A. \& Gabrielyan, N. I. (2018). Antagonistic activity of lactic acid bacteria Lactobacillus spp. against clinical isolates of Klebsiella pneumonia. Applied Biochemistry \& Microbiology, 54(3): 277-287.

Garbeva, P., van Veen, J. A. \& van Elsas, J. D. (2003). Predominant Bacillus spp. in agricultural soil under different management regimes detected via PCR-DGGE. Microbial Ecology, 45: 302-316. https://doi.org/10.1007/s00248-002-2034-8

Gomez-Gill, B., Roque, A. \& Turnbull, J. F. (2000). The use and selection of probiotic bacteria for use in the culture of larval aquatic organisms. Aquaculture, 191: 259-270

Gopal, P. K., Prasad, J., Smart, J. \& Gill, H. S. (2001). In vitro adherence properties of Lactobacillus rhamnosus DR20 and Bifidobacterium lactis DR10 strains and their antagonistic activity against an enterotoxigenic Escherichia coli. International Journal of Food Microbiology, 67: 207-216.

Hall, T. A. (1999). BioEdit: A user-friendly biological sequence alignment editor and analysis program for Windows 95/98/NT. Nucleic Acids Symposium Series. 95-98.

Heumann, W. (1960). Versuche zur Rekombination Sternbildender Bakterien. Naturwissenschaften, 47: 330-331.

İçgen, B. \& YIImaz, F. (2014). Co-occurrence of antibiotic and heavy metal resistance in KIzlırmak River isolates. Bulletin of Environmental Contamination and Toxicology, 93: 735-743.

Irkitova, A. N., Grebenshchikova, A. V. \& Matsyura, A. V. (2018). Antagonistic activity of Bacillus subtilis strains isolated from various sources. Ukrainian Journal of Ecology, 8(2): 354-364.

Jeong, S. J., Heo, K., Park, J. Y., Lee, K. W., Park, J. Y., Joo, S. H. \& Kim, J. H. (2015). Characterization of AprE176, a fibrinolytic enzyme from Bacillus subtilis HK176. Journal of Microbiology and Biotechnology, 25(1): 89-97.

Kan, N. İ. \& Sarıeyyüpoğlu, M. (2008). Investigation of streptococci in fish caught from region of Elaziğ city sewage discharged into Keban Dam Lake. Firat Üniversitesi Fen Bilimleri Dergisi, 20(2): 271-277. (In Turkish)

Katırcıoğlu, H. (2001). Gökkușağı Alabalığı ve Aynalı Sazandan izole edilen laktik asit bakterilerinin metabolik ve antimikrobiyal aktivitelerinin incelenmesi. Gazi Üniversitesi Fen Bilimleri Enstitüsü Biyoloji Ana Bilim Dalı, Doktora tezi, 139, Ankara.

Kavuthodi, B. \& Sebastian, D. (2018). Review on bacterial production of alkaline pectinase with special emphasis on Bacillus species. Bioscience Biotechnology Research Communications, 11(1): 18-30.

Kim, H.S., Lee, O. K., Lee, S. J., Hwang, S., Kim, S. J., Yang, S. H., Park, S. \& Lee, E. Y. (2006). Enantioselective epoxide hydrolase activity of a newly isolated microorganism, Sphingomonas echinoides EH-983, from seawater. Journal of Molecular Catalysis B: Enzymatic, 41: 130-135. https:// doi.org/10.1016/j.molcatb.2006.05.009

Kimura, S., Bryan, C. G., Hallberg, K. B. \& Johnson, D. B. (2011). Biodiversity and geochemistry of an extremely Acidic, low-temperature subterranean environment sustained by chemolithotrophy. Environmental Microbiology, 13(8):2092-2104. https://doi.org/10.1111//.14622920.2011.02434.x

Lane, D.J. (1991). 16S/23S rRNA sequencing. In: Nucleic Acid Techniques in Bacterial Systematics, Ed. E. Stackebrandt and M. Goodfellow. John Wiley and Sons, Chichester. 115-175.

Larkin, M. A., Blackshields, G., Brown, N., Chenna, R., Mcgettigan, P. A., Mcwilliam, H., Valentin, F., Wallace, I. M., Wilm, A. \& Lopez, R. (2007). Clustal W and Clustal X version 2.0. Bioinformatics. 23: 2947-2948.

Lee, M. J., Lee, J. J., Chung, H. Y., Choi, S. H. \& Kim, B. S. (2016). Analysis of microbiota on abalone (Haliotis discus hannal) in South Korea for Improved product management. International Journal of Food Microbiology, 234: 45-52.

Li, Z., Bai, Z., Zhang, B., Xie, H., Hu, Q., Hao, C., Xue, W. \& Zhang, H. (2005). Newly isolated Bacillus gibsonii S-2 Capable of using sugar beet pulp for alkaline pectinase production. World Journal of Microbiology \& Biotechnology, 21:1483-1486. https://doi.org/10.1007/s11274-005-7025-8

Logan, N. A. \& De Vos, P. (2009). Genus: Bacillus, Bergey's manual of systematics bacteriology Vol III, Springer Dordrecht Heidelberg London New York, 21-128.

Ma, Y. X., Li, L. Y., Bao, P. Y., Li, M., Chen, W. \& Chang Y. Q. (2018). Effects of combined dietary administration of Rhodotorula sp. H26 and Bacillus sp. BC26 on growth, immunity and intestinal microbiota in juvenile Sea Cucumber, Apostichopus japonicus. Aquaculture Research, 49: 37923803.

Muz, A., Sarıeyyüpoğlu, M., Ertaș, H. B. \& Șimșek, A. (1995). Keban Baraj Gölü’nden yakalanan bazı balıkların aerobik ve mikroaerofilik bakteriler yönünden incelenmesi. Firat Üniversitesi Sağlık Bilimleri Dergisi, 9(2): 212-219.

Nannan, C., Vu, H. Q., Gillis, A., Gaulier, S., Nguyen, T. T. T. \& Mahillon, J. (2021). Bacilysin within the Bacillus subtilis Group: Gene Prevalence versus antagonistic activity against Gram-negative foodborne pathogens. Journal of Biotechnology, 327: 28-35.

Orozova, P., Sirakov, I., Austin, D. A. \& Austin, B. (2018). Recovery of Bacillus mycoides, B. pseudomycoides and Aeromonas hydrophila from common carp (Cyprinus carpio) and Rainbow Trout (Oncorhynchus mykiss) with gill disease. Journal of Fish Diseases, 41(1): 125-129.

Özer, G., Ergene, A. \& İçgen, B. (2013). Biochemical and molecular characterization of strontium-resistant environmental isolates of Pseudomonas fluorescens and Sphingomonas paucimobilis. Geomicrobiology Journal, 30: 381-390. https://doi.org/10.1080/01490451.2012.694977

Özer, S., Demirel, M., Us, M. \& Yıldırım, S. (2008). Microbial flora of rainbow trout (Oncorhynchus mykiss, Walbaum) hatcheries in Çağlarca, province Mersin-Turkey. Journal of FisheriesSciences.com, 2(3): 261-271. (In Turkish) https://doi.org/10.3153/ifscom.mug.200713

Öztürk, T., Didinen, B. I., Doğan, G., Özer, A. \& Bircan, R. (2013). Lactococcosis in Rainbow Trout (Oncorhynchus mykiss, Walbaum, 1792) in the Middle Black Sea Region in Turkey and antimicrobial susceptibility of the aetiological agent, Lactococcus garvieae. Etlik Vet Mikrobiyol Derg, 24:712. 
Pandey, A. K., Patel, A. K., Banjare, U. \& Singh, R. K. (2021). Molecular characterization of bacterial microbiome isolated from wheat rhizosphere of agro climatic zones of India. Indian Journal of Natural Sciences, 12(67): 33033-33042.

Piccini, C., Conde, D., Alonso, C., Sommaruga, R. \& Pernthalter, J. (2006). Blooms of single bacterial species in a coastal lagoon of the Southwestern Atlantic Ocean. Applied and Environmental Microbiology, 72(10): 6560-6568. https://doi.org/10.1128/AEM.01089-06

Rafat, A., Philip, K. \& Muniandy, S. (2012). A novel source of bioactive compounds: Endophytic bacteria isolated from Centella asiatica. Journal of Pure and Applied Microbiology, 6(1): 11-20.

Ringo, E. \& Gatesoupe, F. J. (1998). Lactic acid bacteria in fish: a review. Aquaculture, 160: 177-203.

Roberts, R. J. (2012). Fish pathology $4^{\text {th }}$ edition, Wiley-Blackwell, UK.

Sezen, K., Ișci, Ș., Muratoğlu, H., İnan, K. \& Demirbağ, Z. (2013). Identification and pathogenicity of bacteria from Gryllotalpa gryllotalpa L. (Orthoptera: Gryllotalpidae). Türkiye Biyolojik Mücadele Dergisi, 4(2): 89-108.

Shin, S. C., Kim, S. J., Ahn, D. H., Lee, J. K. \& Park, H. (2012). Draft genome sequence of Sphingomonas echinoides ATCC 14820. Journal of Bacteriology, 194(7): 1843.

Singh, B. R., Agrawal, R., Vadhana, P., Bhardwaj, M. \& Dubey, S. (2015). Antimicrobial activity of citronella essential oil on antimicrobial drug resistant bacteria from veterinary clinical cases. Clinical \& Medical Biochemistry, 1(1): 1000106.

Tambekar, D. H. \& Dhundale, V. R. (2012). Studies on the physiological and cultural diversity of bacilli characterized from Lonar Lake (Ms) India. Bioscience Discovery, 3(1): 34-39.

Taș, B. (2006). Investigation of water quality of Derbent Dam Lake (Samsun). Ekoloji, 60:1-6.

TUIK (2020). Turkish Statistical Institute Retrieved on November 06, 2020 from https://tuikweb.tuik.gov.tr/PreTablo.do?alt id=1005

Tuo, Y., Zhang, W., Zhang, L., Ai, L., Zhang, Y., Han, X. \& Yi, H. (2013). Study of probiotic potential of four wild Lactobacillus rhamnosus strains. Anaerobe, 21: $22-27$

Türe, M., Altınok, İ., Ișıdan, H., Savaș, H. \& Kutlu, İ. (2012). PFGE metodu kullanılarak Lactoccoccus garvieae'nin genetik çeșitliliğinin ve yayılımının belirlenmesi, TAGEM Proje Sonuç Raporu. Su Ürünleri Merkez Araștırma Enstitüsü, Trabzon.

Verdenelli, M. C., Ghelfi, F., Silvi, S., Orpianesi, C., Cecchini, C. \& Cresci, A. (2009). Probiotic properties of Lactobacillus rhamnosus and Lactobacillus paracasei isolated from human faeces. European Journal of Nutrition, 48: 355-363.

Wikler, M. (2006). Performance Standards for Antimicrobial Susceptibility Testing. Wayne, PA; Clinical and Laboratory Standards Insitute.

Yabuuchi, E. \& Kosako, Y. (2005). Genus: Sphingomonas Bergey's manual of systematics bacteriology Vol II part C, Springer Dordrecht Heidelberg London New York, 21-128.

Yuan, X., Zhou, Y., Liang, X.F., Guo, X., Fang, L., Li, J., Liu, L. \& Li, B. (2015). Effect of dietary glutathione supplementation on the biological value of rapeseed meal to juvenile Grass Carp, Ctenopharyngodon idellus. Aquaculture Nutrition, 21: 73-84. https://doi.org/10.1111/anu.12142

Zhang, B., Fan, R., Bai, Z., Wang, S., Wang, L. \& Shi, J. (2013). Biosorption characteristics of Bacillus gibsonii S-2 waste biomass for removal of lead (II) from aqueous solution. Environmental Science and Pollution Research, 20: 1367-1373. https://doi.org/10.1007/s11356-012-1146-z

Zhang, Z., Schwartz, S., Wagner, L. \& Miller, W. (2000). A greedy algorithm for aligning DNA sequences. Journal of Computational Biology, 7: $203-214$.

Zhou, Y., Yuan, X., Liang, X.F., Fang, L., Li, J., Guo, X., Bai, X. \& He, S. (2013). Enhancement of growth and intestinal flora in Grass Carp: The Effect of exogenous cellulose. Aquaculture, 416-417: 1-7. 